\title{
Human-modified landscape acts as refuge for mammals in Atlantic Forest
}

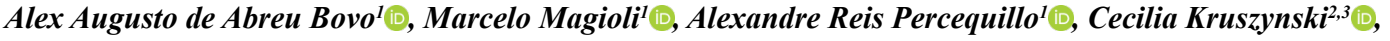 \\ Vinicius Alberici ${ }^{1}{ }^{\oplus}$, Marco A. R. Mello $^{4}{ }^{\circ}$, Lidiani Silva Correa ${ }^{1}$,João Carlos Zecchini Gebin ${ }^{1}$, Yuri Geraldo \\ Gomes Ribeiro $^{1} \mathbb{D}^{\mathbb{D}}$, Francisco Borges Costa ${ }^{5}$, Vanessa Nascimento Ramos ${ }^{5}$, Hector Ribeiro Benatti ${ }^{5}$, Beatriz \\ Lopes $^{1}$, Maísa Z. A. Martins ${ }^{1}$, Thais Rovere Diniz-Reis ${ }^{2}{ }^{1}$, Plínio Barbosa de Camargo $^{6}$, Marcelo Bahia \\ Labruna $^{5} \mathbb{D}$ \& Katia Maria Paschoaletto Micchi de Barros Ferraz ${ }^{1^{*}(\mathbb{D})}$ \\ ${ }^{1}$ Universidade de São Paulo, Escola Superior de Agricultura "Luiz de Queiroz", Departamento de Ciências \\ Florestais, Laboratório de Ecologia, Manejo e Conservação da Fauna Silvestre, Av. Pádua Dias, 11, \\ 13418-900, Piracicaba, SP, Brasil \\ ${ }^{2}$ Universidade de São Paulo, Centro de Energia Nuclear na Agricultura, Piracicaba, SP, Brasil \\ ${ }^{3}$ Leibniz Institut fur Zoo und Wildtierforschung eV, Berlin, Germany \\ ${ }^{4}$ Universidade Federal de Minas Gerais, Biologia Geral, Belo Horizonte, MG, Brasil \\ ${ }^{5}$ Universidade de São Paulo, Faculdade de Medicina Veterinária e Zootecnia, Departamento de Medicina \\ Veterinária Preventiva e Saúde Animal, São Paulo, SP Brasil \\ ${ }^{6}$ Universidade de São Paulo, Centro de Energia Nuclear na Agricultura, CENA - Laboratório de Ecologia \\ Isotópica, Piracicaba, SP, Brasil \\ *Corresponding author: Katia Maria Paschoaletto Micchi de Barros Ferraz,e-mail: katia.ferraz@usp.br
}

BOVO, A.A.A, MAGIOLI, M.; PERCEQUILLO, A.R., KRUSZYNSKI, C., ALBERICI, V., MELLO, M.A.R., CORREA, L.S., GEBIN, J.C.Z., RIBEIRO, Y.G.G., COSTA, F.B.; RAMOS, V.N., BENATTI, H.R., LOPES, B., MARTINS, M.Z.A., DINIZ-REIS, T.R., CAMARGO, P.B.; LABRUNA, M.B., FERRAZ, K.M.P.M.B. Human-modified landscape acts as refuge for mammals in Atlantic Forest. Biota Neotropica. 18(2): e20170395. http://dx.doi.org/10.1590/1676-0611-BN-2017-0395

\begin{abstract}
Human-modified landscapes (HMLs) are composed by small, isolated and defaunated forest fragments, which are surrounded by agricultural and urban areas. Information on species that thrives in these HMLs is essential to direct conservation strategies in local and regional scales. Since HMLs are dominant in the Atlantic Forest, we aimed to assess the mammalian diversity in a HML in southeastern Brazil and to propose conservation strategies. We collected data of terrestrial (small-, medium- and large-sized) and volant mammals in three small forest fragments (10, 14 and 26 ha) and adjacent areas, between 2003 and 2016, using complementary methods: active search, camera trapping, live-traps, mist nets and occasional records (i.e., roadkills). In addition, we used secondary data to complement our species list. We recorded 35 native mammal species ( 6 small-sized, 16 mediumand large-sized, and 13 bats) and seven exotic species in the HML. The recorded mammal assemblage (non-volant and volant), although mainly composed of common and generalist species, includes three medium- and large-sized species nationally threatened (Leopardus guttulus, Puma concolor and Puma yagouaroundi) and two data deficient species (Galictis cuja and Histiotus velatus), highlighting the importance of this HML for the maintenance and conservation of mammal populations. Despite highly impacted by anthropogenic disturbances, the study area harbors a significant richness of medium- and large-sized mammals, being an important biodiversity refuge in the region. However, this biodiversity is threatened by the low quality of the habitats, roadkills and abundant populations of domestic cats and dogs. Therefore, we stress the need of conservation strategies focusing on the medium- and large-sized mammals as an umbrella group, which could benefit all biodiversity in the landscape. We recommend actions that promotes biological restoration, aiming to increase structural composition and connectivity of the forest fragments, reducing roadkills and controlling the domestic cats and dogs' populations, in order to maintain and improve the diversity of mammals in long-term.
\end{abstract}

Keywords: Mammalia, Inventory, Conservation, Forest Remnants, Agroecosystem. 


\title{
Paisagem antropicamente modificada atua como refúgio para mamíferos na Mata Atlântica
}

\begin{abstract}
Resumo: Paisagens antropicamente modificadas (HMLs) são compostas por fragmentos florestais pequenos, isolados e defaunados, imersos em áreas agrícolas e/ou urbanas. Informações sobre as espécies que habitam essas paisagens são importantes para o direcionamento de estratégias de conservação em escalas local e regional. Uma vez que as HMLs são as paisagens dominantes na Mata Atlântica, o objetivo deste trabalho foi avaliar a diversidade de mamíferos em uma HML do sudeste do Brasil e propor estratégias para sua conservação. Foram coletados dados de mamíferos terrestres (pequenos, médios e grandes) e voadores em três fragmentos florestais (10, 14 e 26 ha) e áreas adjacentes, entre 2003 e 2016, usando métodos complementares: busca ativa, armadilhamento fotográfico, armadilhas de captura e redes de neblina. Adicionalmente, foram utilizados dados de literatura para complementar a lista de espécies. Foram registradas 35 espécies de mamíferos nativos ( 6 de pequenos, 16 de médios e grandes e 13 de morcegos) e sete espécies exóticas. A assembleia de mamíferos registrada (terrestres e voadores), embora composta por espécies generalistas, apresentou três espécies de médio e grande porte ameaçadas de extinção nacionalmente (Leopardus guttulus, Puma concolor and Puma yagouaroundi) e duas deficientes em dados (Galictis cuja and Histiotus velatus), destacando a importância dessa HML para conservação e manutenção das populações de mamíferos. Embora inserida em uma paisagem extremamente modificada, a área de estudo abriga uma riqueza significativa de mamíferos de médio e grande porte, sendo um importante refúgio para a biodiversidade na região. Entretanto, essa biodiversidade está ameaçada pela baixa qualidade dos habitats, por atropelamentos e por abundantes populações de cães e gatos domésticos. Portanto, enfatizamos a necessidade de estratégias de conservação focadas nos mamíferos de médio e grande porte como grupo "guarda-chuva", o que pode beneficiar as demais espécies na paisagem. Recomendamos ações de conservação visando a restauração biológica, para melhorar a composição estrutural e conectividade dos fragmentos florestais, reduzir o número de atropelamentos e controlar as populações de cães e gatos domésticos, afim de manter e aumentar a diversidade local de mamíferos em longo prazo.
\end{abstract}

Palavras-chave: Mammalia, Inventário, Conservação, Fragmentos florestais, Agroecossistema.

\section{Introduction}

Economic development demands large amounts of land, modifying natural areas and creating human-modified landscapes (HMLs). HMLs are defined as areas composed by small and isolated forest fragments, usually defaunated and surrounded by agricultural and urban areas (Melo et al. 2013). The Brazilian Atlantic Forest is an example of a human-modified tropical forest, with only 11 to $15.3 \%$ of its original cover remaining (Ribeiro et al. 2009; SOS Mata Atlântica, 2017). This biome was strongly modified during the last centuries (Dean 1997), and nowadays is mainly composed by HMLs (Ribeiro et al. 2009).

The fauna inhabiting HMLs faces challenges due to the human activities (Peres et al. 2010), which alters the environment and reduces habitat availability. Nevertheless, these areas still act as habitat for a considerable number of resilient vertebrate species, such as mammals (Chiarello 2000a; Bogoni et al. 2013; Magioli et al. 2014a, 2016; Beca et al. 2017). Although most mammal species within HMLs are considered habitat-generalists, some threatened species can be found (Dotta \& Verdade 2011; Reale et al. 2014; Magioli et al. 2016), also performing important ecological functions (Magioli et al. 2015).

For most of the remaining Brazilian Atlantic Forest, HMLs became the dominant landscape, usually harboring defaunated subsets of the assemblages found in less altered habitats (Silva Jr. \& Pontes 2008; Jorge et al. 2013). Furthermore, the situation tends to get worse, as brazilian environmental laws have been recently altered to favor economic development (Laws $\mathrm{N}^{\circ}$ 12.651, from 25/05/2012 and $\mathrm{N}^{\circ}$ 12.727, from 17/10/2012; Stickler et al. 2013; Soares-Filho et al. 2014). Therefore, there is a need for assessing the remaining biodiversity in HMLs, as a first step for the maintenance of those communities, and their associated ecosystem functions and services. With this aim, we carried out an inventory of non-volant (small-, medium- and large-sized) and volant mammals in small forest fragments in a HML in southeastern Brazil, providing a diversity assessment that will allow future directions toward their conservation.

\section{Material and Methods}

\section{Study site}

We carried out this study in two areas in Piracicaba, state of São Paulo, southeastern Brazil: ESALQ (Escola Superior de Agricultura "Luiz de Queiroz", Universidade de São Paulo) and IPEF (Instituto de Pesquisas Florestais; Figure 1). Both areas are located in the Atlantic Forest biome, close to the Cerrado boundaries (IBGE 2004), with semideciduous forest fragments. Together, they cover 913.3 ha (874.3 ha from ESALQ and 39 ha from IPEF) and are composed of human constructions, agriculture experimental fields, pastures, gardens, watercourses, small forest fragments (i.e., forest remnants and riparian vegetation) and areas under ecological restoration. We selected three 
forest fragments: Mata da Pedreira (14 ha), a secondary semideciduous forest; Mata do Aeroporto (10 ha), a small gallery forest surrounded by Pinus plantation; and Mata do IPEF (26 ha), a semideciduous forest restored in 2005/2006 around a pond (Figure 1). Mata da Pedreira is located $1.75 \mathrm{~km}$ from Mata do Aeroporto and from Mata do IPEF, while the two latter are $550 \mathrm{~m}$ apart from each other. There are three watercourses in the study area - Piracicaba river, the main river on the landscape, Piracicamirim river and a nameless intermittent stream, both tributary of Piracicaba river -, which are surrounded by riparian secondary vegetation that connects most of the studied fragments. The study area is located between Piracicaba city and the agricultural matrix of rural areas, composed mainly by sugarcane. Two protected areas are located near ESALQ and IPEF, Estação Experimental de Tupi (EE Tupi, 7 km in a straight line) and Estação Ecológica de Ibicatu (ESEC Ibicatu, $\sim 22 \mathrm{~km}$ in a straight line).

\section{Data collection}

\subsection{Small non-volant mammals}

Small mammals were sampled in Mata da Pedreira and Mata do Aeroporto (Figure 1). We carried out a conventional trapping, with Sherman and Tomahawk traps (Voss \& Emmons 1996). We sampled
Mata da Pedreira from July 22 to 27, 2015, where we installed five trap-lines; each trap-line was composed of five sampling stations, and each station had three traps (one tomahawk and one Sherman on the ground, and one Sherman on bushes or small trees, at a minimum height of $1.5 \mathrm{~m}$ ). This resulted in a sampling effort of 375 trap-nights.

In Mata do Aeroporto, sampling was carried out from November 30 to December 4, 2015, and from June 13 to 17, 2016. In this sampling site, we installed 13 trap-lines resulting in a total sampling effort of 780 trap-nights in each campaign (1,560 trap-nights). Small mammal species recorded by active search (see below in item 2.3) were also included in the inventory.

\subsection{Small volant mammals}

Bats were sampled in two periods, 23 nights from December 2003 to May 2004, and 11 nights from December 2013 to June 2015, in a total sampling effort of 32,970 h.m² (see Straube \& Bianconi 2002). As bats are flying species, besides to Mata da Pedreira, we also sampled other five sites in ESALQ, closer to urban and agricultural areas (Figure 1). For the first period, nets were placed on trails within forest fragments and on the edges. In the second sampling period, nets were placed randomly on the campus and around the urban area, where we found evidence of bat roosts (e.g., feces) in nearby buildings. At each site,

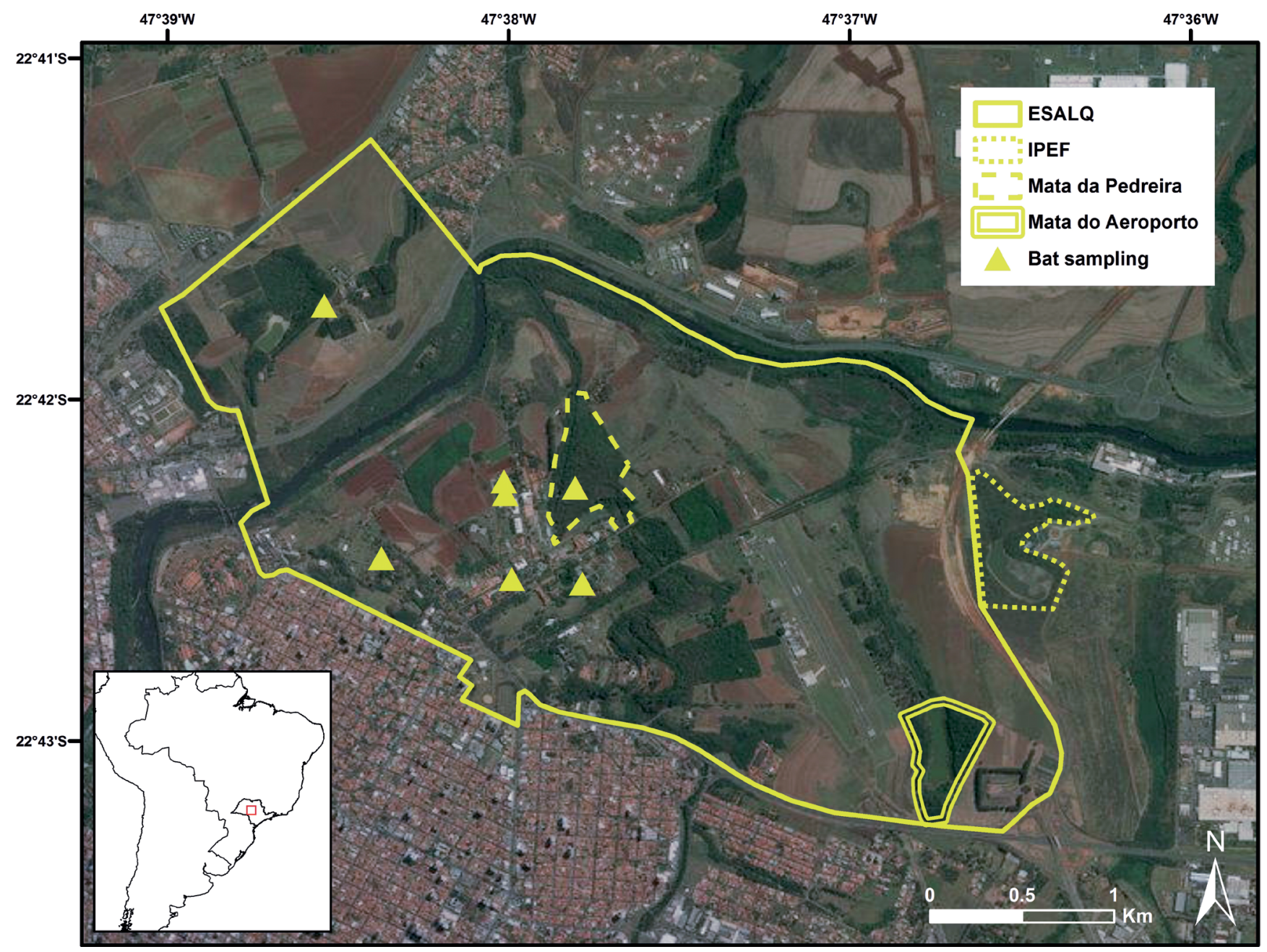

Figure 1. Study area located in southeastern Brazil, at Piracicaba municipality, state of São Paulo. The studied forest fragments are highlighted. 
we opened three to six mist nets at sunset and closed after six hours of sampling. Net size ranged from $10 \times 3 \mathrm{~m}$ to $12 \times 3 \mathrm{~m}$ with $2.5 \mathrm{~mm}$ mesh (Ecotone Inc., Poland).

We identified all captured individuals and determined sex, age class and reproductive status; body was measured on forearm length and weight. Bats were identified to the finest possible taxonomic level by using specialized keys (Gregorin \& Taddei 2002; Gardner 2007). The age classes (infant, juvenile or adult) were estimated based on the degree of ossification of the phalangeal epiphyses (Kunz and Anthony 1982).

\subsection{Medium- and large-sized mammals}

We considered as medium-sized mammals those weighing between 1 and $7 \mathrm{~kg}$ (Chiarello 2000b), and those weighing over $7 \mathrm{~kg}$ were considered large-sized (Emmons \& Feer 1997). However, species of the genus Didelphis (weighing more than $1 \mathrm{~kg}$ ) were considered small-sized, because they are commonly recorded in small mammal inventories, as well as species of the genus Callithrix (weighing less than $1 \mathrm{~kg}$ ), which where considered in the medium- and large-sized category, for being commonly recorded in medium- and large-sized mammal inventories. We used two sampling methods - camera traps and active search - in Mata da Pedreira and IPEF fragment. We collected data using both methods in Mata da Pedreira from March to December 2012, and in IPEF between February 2011 and June 2013.

Sampling occurred for approximately five days in each month in a non-systematized way. We distributed five to eight camera traps (Bushnell 12 MP Trophy Cam HD) in both areas, resulting in a trapping effort of 1068 camera trap days (216 camera trap days in ESALQ, and 852 camera trap days in IPEF).

The active search method consisted of walking on dirt roads and trails inside the forest fragments, at an average speed of $1 \mathrm{~km} / \mathrm{h}$, searching for direct (i.e., sightings, vocalizations, carcasses) and indirect (i.e., tracks, feces, burrows, food leftovers) evidence of mammalian activity (Voss \& Emmons 1996). This method was conducted simultaneously to the camera trapping.

During sampling, we carefully measured and photographed all visible mammal tracks, and then compared our evidence with field guides (Becker \& Dalponte 1999; Oliveira \& Cassaro 2005; Borges \& Tomás 2008). To identify other medium- and large-sized mammal evidence (e.g. vestiges, sightings, vocalizations) and camera trap photos, we consulted specialized literature (Emmons \& Feer 1997; Oliveira \& Cassaro 2005; Borges \& Tomás 2008) and experts (Tadeu de Oliveira for Leopardus guttulus and Mauricio Barbanti for Mazama gouazoubira).

We complemented our inventory with species recorded by a previous study, between 2001 and 2002, in areas that have not been much altered since then (Gheler-Costa et al. 2002). We also included occasional records of roadkilled mammals in a road that bisects ESALQ. This unstandardized sampling method also recovered medium- and large-sized mammal species that are preserved as vouchers at the Laboratório de Mamíferos, ESALQ, USP (LMUSP) (see Appendix 1).

\section{Data analysis}

For small non-volant mammals, we assessed the capture success in each forest fragment, and for the whole sampling, we used the relative frequency of captures by total sampling effort (total of trap-nights). We estimated species richness for medium- and large-sized mammals (only camera trap data) and bats using the first-order Jackknife, since this index is based on species recorded only once. We calculated the indexes only for these groups because the other methods for mediumand large-sized mammals were not standardized, and the number of small non-volant mammals captured was very low. We assigned threat categories (i.e., vulnerable, endangered, critically endangered) following Percequillo \& Kierulff (2009), Brasil (2014) and IUCN (2016). Species nomenclature followed Paglia et al. (2012), Trigo et al. (2013) and Patton et al. (2015). We considered exotic species those occurring outside its natural range, as defined in Falk-Petersen et al. (2006). For bats, we also described the structure of the local assemblage using the recorded species list, a species richness index and an abundance distribution plot. We performed all analyses in R 3.2.4 (R Core Team 2016) using the packages 'bootstrap' and 'vegan'.

\section{Ethical procedures}

We carried out the fieldwork with small mammals following the guidelines of the American Society of Mammalogists (Sikes \& Animal Care and Use Committee of the American Society of Mammalogists, 2016). We had permits from the Instituto Chico Mendes de Conservação da Biodiversidade (SISBIO \#41352-1, for bats; \#14419-1 and \#43259-3, for marsupials and rodents) and from the Ethics Committee for Animal Experimentation of the Centro de Energia Nuclear na Agricultura (protocol \#2013-18, for bats) and of the ESALQ (protocol \#2014-29, for marsupials and rodents). Two bats individuals of each species captured were collected as vouchers for accurate identification and were deposited at the Laboratório de Mamíferos, ESALQ, USP (LMUSP) and at the Universidade Federal de Minas Gerais (UFMG; see Appendices 1 and 2).

\section{Results}

We recorded 42 mammal species, belonging to 18 families and 8 orders. Among them, seven were small non-volant species, 22 medium- and large-sized species and 13 volant species, including seven exotic species (one small-sized and six medium- and large-sized) (Table 1; Figure 2; Appendices 3 and 4). Four species were recorded only by literature data: Lutreolina crassicaudata, Callithrix jacchus, Calomys temer and Cavia aperea.

\section{Small non-volant mammals}

The sampling effort in Mata da Pedreira recorded eight individuals from two small mammal species, Didelphis albiventris and Oligoryzomys nigripes, with a low capture success (2.1\%; see Appendix 1, with the list of specimens examined). In Mata do Aeroporto, the capture success was even lower $(0.57 \%)$, consisting of nine individuals of three species, D. albiventris, Didelphis aurita and O. nigripes. Other two native small mammals were added to our list from previous inventories carried out in the study area (Table 1). No species of small non-volant mammals recorded was threatened in local, national or global scale.

\section{Small volant mammals}

At ESALQ, we captured 533 bat individuals of 13 species and three families. The most diverse family was Phyllostomidae, with eight species, followed by Molossidae and Vespertillionidae, with three and two species, respectively. First-order Jackknife estimated a richness species of $16.75( \pm 2.32)$. The most abundant and diverse 

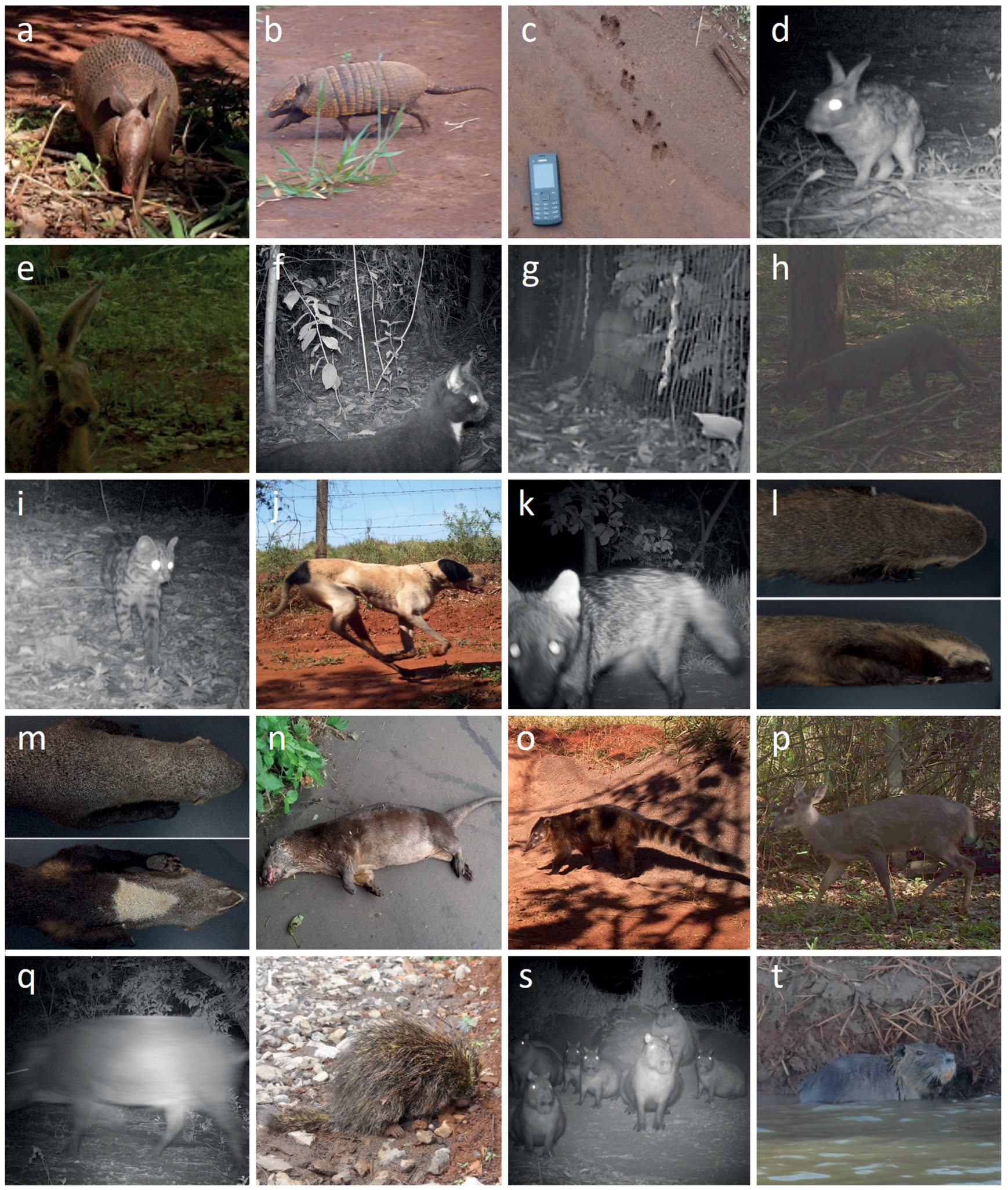

Figure 2. Recorded medium- and large-sized mammals at Piracicaba, state of São Paulo, Brazil: a: Dasypus novemcinctus; b: Euphractus sexcinctus; c: Dasypus septemcinctus footprints; d: Sylvilagus brasiliensis; e: Lepus europaeus; f: Felis catus; g: Puma concolor (video is available in Appendix 3); h: Puma yagouaroundi; i: Leopardus guttulus; j: Canis familiaris; k: Cerdocyon thous; 1: Galictis cuja; m: Eira barbara; n: Lontra longicaudis; o: Nasua nasua; p: Mazama gouazoubira; q: Sus scrofa; r: Coendou spinosus; s: Hydrochoerus hydrochaeris; t: Myocastor coypus. 
Bovo, A.A.A. et al.

Table 1. Mammal species recorded at ESALQ, IPEF and surrounding areas in Piracicaba, state of São Paulo, Brazil. $\mathrm{T}=\operatorname{tracks} ; \mathrm{C}=\mathrm{camera}$-trap; $\mathrm{S}=$ sighting; $\mathrm{Tr}=$ trapping; $\mathrm{R}=$ references (Gheler-Costa et al. 2002); $\mathrm{Rk}=$ roadkill; $\mathrm{O}=$ carcasses, food leftovers, burrows; $\mathrm{M}=$ mist net; * exotic species; ** voucher specimen; $\mathrm{VU}=$ vulnerable; $\mathrm{DD}=$ data deficient; $\mathrm{SP}=$ São Paulo state; $\mathrm{Br}=$ Brazil; $\mathrm{W}=$ world, $\mathrm{IP}=$ Mata do IPEF, MP = Mata da Pedreira, MA= Mata do Aeroporto.

\begin{tabular}{|c|c|c|c|c|}
\hline Taxon & Common name & Record type & Threaten level & Fragment \\
\hline \multicolumn{5}{|l|}{ DIDELPHIMORPHIA } \\
\hline \multicolumn{5}{|l|}{ Didelphidae } \\
\hline Didelphis albiventris Lund, 1840 & White-eared opossum & $\mathrm{Tr}^{* *}, \mathrm{C}, \mathrm{S}, \mathrm{R}, \mathrm{Rk}$ & & IP, MP, MA \\
\hline Didelphis aurita (Wied-Neuwied, 1826) & Big-eared opossum & $\operatorname{Tr}^{* *}$ & & MA \\
\hline Lutreolina crassicaudata (Desmarest, 1804) & Lutrine opossum & $\mathrm{R}$ & & \\
\hline
\end{tabular}

\section{CINGULATA}

\section{Dasypodidae}

Dasypus novemcinctus Linnaeus, 1758

Dasypus septemcinctus Linnaeus, 1758

Euphractus sexcinctus (Linnaeus, 1758)

\section{PRIMATES}

\section{Callitrichidae}

Callithrix jacchus (Linnaeus, 1758) *

Callithrix penicillata (É. Geoffroy, 1812)

\section{LAGOMORPHA}

Leporidae

Lepus europaeus (Linnaeus, 1758) *

Sylvilagus brasiliensis (Linnaeus, 1758)

\section{CARNIVORA}

Felidae

Felis catus (Linnaeus, 1758) *

Puma concolor (Linnaeus, 1771)

Puma yagouaroundi (É. Geoffroy, 1803)

Leopardus guttulus (Schreber, 1775)

Canidae

Canis familiaris (Linnaeus, 1758) *

Cerdocyon thous (Linnaeus, 1766)

\section{Mustelidae}

Galictis cuja (Molina, 1782)

Eira barbara (Linnaeus, 1758)

Lontra longicaudis (Olfers, 1818)

\section{Procyonidae}

Nasua nasua (Linnaeus, 1766)

\section{ARTIODACTYLA}

\section{Cervidae}

Mazama gouazoubira (G. Fischer, 1814)

Suidae

Sus scrofa (Linnaeus, 1758) *

Nine-banded armadillo

Seven-banded armadillo

Six-banded armadillo

Common marmoset

Black-pencilled marmoset

European hare

Brazilian rabbit

\section{Domestic cat}

Puma

Jaguarundi

Oncilla

Domestic dog

Crab-eating fox

Lesser grisson

Tayra

Neotropical otter

South american coati
Tr**, C, T, S, R, Rk, O

$\mathrm{T}$

C, T, S

$\mathrm{R}$

$\mathrm{S}, \mathrm{Rk}^{* *}$

MP
IP

C, R

IP, MP
IP, MP, MA

IP

IP 
Continued Table 1.

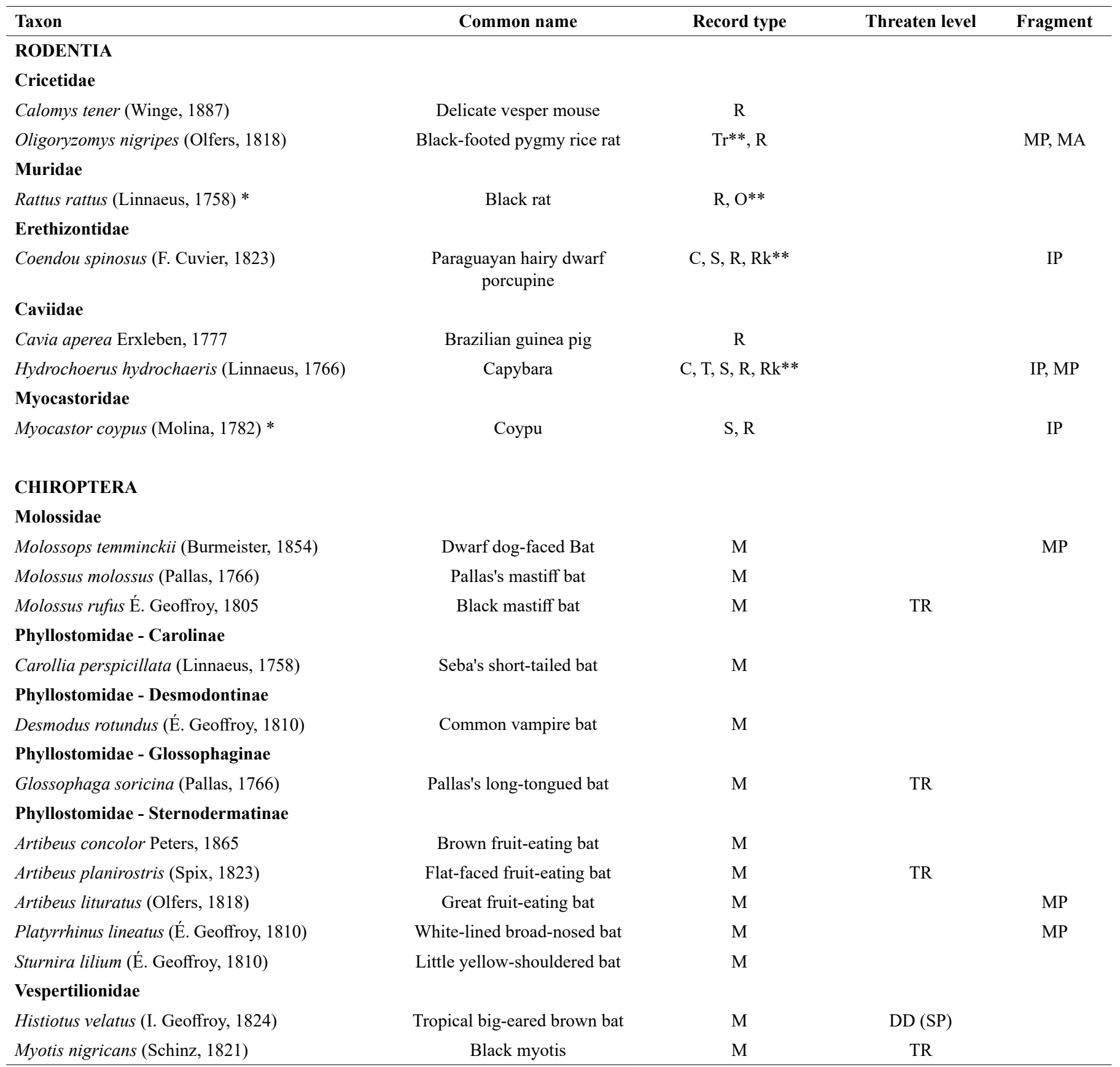

dietary category was frugivorous bats, represented by six species of two subfamilies ( $46 \%$ of the total richness), followed by insectivorous bats with five species (38\%) (Appendices 5 and 6). The other two categories were nectarivorous bats represented by one species $(7 \%)$, and one sanguivorous species (7\%).

Artibeus lituratus (Phyllostomidae) was the most abundant species (57\%), followed by Platyrrhinus lineatus (Phyllostomidae, 11\%), Sturnira lilium (Phyllostomidae, 9\%), Glossophaga soricina and Molossus molossus (Phyllostomidae and Molossidae, respectively, 5\%), A. concolor, Carollia perspiscillata, Histiotus velatus (Phyllostomidae and Vespertilionidae, 2\%) while A. planirostris, Desmodus rotundus, Molossus rufus, Molossops temminckii and Myotis nigricans were very rare (Phyllostomidae, Molossidae and Vespertilionidae, respectively, $0.18 \%$ ). The bat assemblage recorded in the area had no threatened species, however, some of them have been considered in need of taxonomic revision (A. planirostris, G. soricina, Molossus rufus, $M$. molossus, $H$. velatus, $C$. perspiscillata and Myiotis nigricans) or as data deficient (Molossops temminckii) (Table 1).

\section{Medium- and large-sized mammals}

We recorded 22 species, including six exotics: Callithrix jacchus, Myocastor coypus, Felis catus, Canis familiaris, Lepus europaeus and Sus scrofa; the first two species are from our native fauna of Neotropical South America, and the remaining species from other zoogeographic regions. 
The active search method resulted in the record of 14 species; Dasypus septemcinctus was recorded only by tracks (Figure 2). We also recorded 11 roadkilled species; these are the only records for Eira barbara, Galictis cuja and Lontra longicaudis in our study area (although one of the authors, ARP, sighted an individual of $L$. longicaudis $7 \mathrm{~km}$ away from the study area in 2012).

Using the camera trap method, we obtained 187 records of mammals, resulting in 15 species. Sylvilagus brasiliensis, Puma yagouaroundi, Leopardus guttulus and Sus scrofa were exclusively recorded by this method. The first-order Jackknife for camera trapping estimated a species richness of $15.25( \pm 2.5)$.

The order Carnivora showed the largest number of species $(\mathrm{N}=8)$, distributed in four families: Canidae, Felidae, Mustelidae and Procyonidae. Two species are considered threatened in São Paulo: $L$. guttulus and Puma concolor (Table 1). These two species, as well as $P$. yagouaroundi, are also considered threatened in Brazil. At the global scale, only L. guttulus is considered threatened. G. cuja is considered data deficient in the state of São Paulo.

Armadillos (Cingulata) were also present in the area, with three species. The seven-banded armadillo D. septemcinctus was recorded only once, in contrast to the records of D. novemcinctus $(\mathrm{N}=27)$ and Euphractus sexcinctus $(\mathrm{N}=5)$. Other orders (Primates, Lagomorpha, Artiodactyla) were represented by just one native species.

\section{Discussion}

The mammal assemblage was mainly composed by species commonly found in anthropogenic areas. Nonetheless, some species, such as the threatened carnivores highlight the role of forest fragments as refuge and as corridors connecting habitats. The absence of more habitat specialists may be due to the location of our study site, between an urban area and an agricultural matrix. The species richness was expected for this HML, and our sampling effort was enough to the mammalian fauna of the area. Forest fragments near the study area also presented similar species richness and composition.

\section{Small non-volant mammals}

We recorded only three species in our trapping sampling effort, but available data from literature and species recorded by the active search method allowed us to increase the number of native species. However, the studied assemblage is very poor and composed by species considered tolerant and resilient to modified habitats (Pardini \& Umetsu, 2006). Species richness in Eucalyptus and sugarcane plantations was higher $(\mathrm{n}=12$ species; Rosalino et al. 2014) and similar ( $\mathrm{n}=7$; Gheler-Costa et al. 2013) than in ESALQ and IPEF, areas with higher habitat diversity. Besides that,we did not recover species previously recorded by GhelerCosta et al. (2002), and this could be explained by some factors: (i) we sampled only one type of habitat, focusing on forest remnants, while Gheler-Costa et al. (2002) sampled several habitats (i.e. exotic tree plantations, pasture and agricultural areas); (ii) we performed a small sampling effort (1,935 trap-nights) versus a much larger effort (7,056 trap-nights) conducted by Gheler-Costa et al. (2002), although our trapping success was higher $(2.1 \%$ and $0.57 \%)$ than that obtained by them $(0.37 \%)$; (iii) those species might have been exterminated by a population of domestic cats established in the area a few years ago (see Campos et al. 2007), that is probably growing due to the habit of visitors of ESALQ to fed these animals and to the lack of management by the local authorities.

\section{Small volant mammals}

The recorded bat assemblage is composed of species commonly found in the state of São Paulo (Nogueira et al. 2014), either in protected areas (Passos et al. 2003), or anthropogenic ones, such as agricultural and urban landscapes (Chaves et al. 2012). Studies in the neighbor municipality found close bat species richness in restoration areas ( $\mathrm{n}=12$ species; Jacomassa 2015) and Eucalyptus plantation $(\mathrm{n}=9$ species; Bortolotti 2015). HMLs near urban areas usually harbor poor communities (Avila-Flores \& Fenton 2005; Siles et al. 2005; Pacheco et al. 2010; Jung \& Kalko 2011), as found in the present study. This group also presented lower species richness and relative abundance of bats, and a high dominance by a few species, mainly from the subfamilies Sternodermatinae and Glossophaginae, and the family Molossidae (Bredt \& Uieda 1996; Filho 2011), when compared to preserved areas.

\section{Medium- and large-sized mammals}

Contrasting with the small mammals (volant and non-volant), the richness of native medium- and large-sized mammals $(n=17)$ was high considering the size of the forest fragments and the landscape characteristics. This richness represents $\sim 35 \%$ of all medium- and large-sized mammals that occurs in the state of São Paulo (Vivo et al. 2011). A previous study at ESALQ appointed a lower species richness (ten medium- and large-sized mammals; Gheler-Costa et al. 2002), possibly because of the smaller sample effort and methods used. The recorded species richness is similar to other small Atlantic Forest or Cerrado fragments inserted in HMLs (Chiarello 2000a; Saciloto 2009; Reale et al. 2014; Magioli et al. 2016; Santos et al. 2016). Saciloto (2009) recorded Conepatus semistriatus, Procyon cancrivorus and Dasyprocta azarae in a forest fragment near our study area (EE Tupi), species commonly recorded at Atlantic Forest and Cerrado fragments (Bogoni et al. 2013; Pereira et al. 2013; Magioli et al. 2014a; Reale et al. 2014; Santos et al. 2016), but absent in our study. The capybara, Hydrochoerus hydrochaeris, has a large population in the area, a species that is favored by the habitat and food resource availability in HMLs (Ferraz et al. 2009), also showing up as a common roadkill (Bovo et al. 2016). Despite not being native of our study area, $C$. penicillata distribution limits is close to our study area (Rylands et al. 2009), suggesting that this species may be expanding its range. They may also impact local wildlife by preying on native birds (Alexandrino et al., 2012). C. jacchus is an exotic species, from the northern part of the Atlantic Forest (Rylands et al. 2009), introduced many years ago, but it was not sighted anymore in the study area and it is possibly absent.

The presence of three threatened species highlights the conservation value of these small forest fragments to this group. The largest predator remaining, $P$. concolor, is frequently recorded in HMLs (Lyra-Jorge et al. 2010; Dotta \& Verdade 2011; Reale et al. 2014; Magioli et al. 2016; Santos et al. 2016), and seems to be adapted to agricultural areas, using them as food source and habitat (Magioli et al. 2014b). But these forest fragments, which are close to each other, along with the riparian vegetation alone, cannot support viable populations of most of the recorded species, especially the large-bodied ones and those with large home ranges such as $P$. concolor, L. guttulus, P. yagouaroundi and $M$. gouazoubira. However, these fragments act as stepping-stones and 
biological corridors for the fauna, which are essential for maintaining species diversity, genetic flow and functional diversity (Lyra-Jorge et al. 2010; Miotto et al. 2014; Magioli et al. 2015, 2016) and, therefore, should be targets for biological restoration. The restoration of riparian vegetation could be strengthened in areas that favors a connection between the studied HML and EE Tupi, which may augment habitat availability for species with large home ranges. Other problem to be addressed in this HML is the constant presence of domestic dogs and cats, which are known to transmit diseases and to predate wildlife, besides to compete for resources with wild carnivores (Campos et al. 2007).

\section{Implications for conservations}

Some applicable strategies can increase the effectiveness of the studied HML as a refuge for biodiversity, especially for medium- and large-sized mammals, which showed a richest assemblage than the other groups assessed. Moreover, improving habitat quality focusing on medium- and large-sized mammals may act as an umbrella strategy, favoring all biodiversity in the landscape, such as forest bird species that occurs in this HML (Alexandrino et al. 2013). Although forest remnants and riparian vegetation form structural corridors, they are degraded and fragmented, particularly considering the road that bisects ESALQ and the fragments, which acts as a population sink to local biodiversity. Therefore, in order to maintain long-term populations of large mammals in this HML, and to ensure safety conditions to drivers, we suggest the implementation of safe crossing passages to the fauna, both underpasses and overpasses, combined with fencing along the road (Beckmann et al. 2010, Teixeira et al. 2013, Huijser et al. 2016, Rytwinski et al. 2016). These measures may cause a positive impact over mammal populations, reducing the number of roadkilled individuals.

Regarding the forest fragments quality, we suggest biological restoration aiming to improve their structural composition, which is necessary to shelter species, providing food resources and fulfilment of biological and physiological needs (Benayas et al. 2009), also reducing edge effects. In addition, restoration of areas adjacent to riparian forests and small fragments can increase connectivity, which helps to maintain biodiversity and their functions (Ayram et al. 2015; Magioli et al. 2016). Based on our study landscape, the presence of areas with restricted access (the ESALQ university campus and IPEF, as a private property) and constant surveillance increase its potential as refuge for some species. The presence of forest fragments, even being degraded, allow the movement of these mammals in the area, including the threatened species. The intensively modified landscape and the low levels of forest cover highlight the importance of ESALQ and IPEF to local biodiversity.

Finally, one of the most widespread impacts in the study area is the ever-growing number of domestic cats abandoned on ESALQ, a huge threat to biodiversity maintenance due to predation and zoonotic diseases (Woods et al. 2003; Campos et al. 2007; Gerhold \& Jessup 2013; Loss et al. 2013). Feeding cats and dogs is a common practice in ESALQ, which sustains and augment these animal's populations. An awareness and a control program are necessary to stop the abandon and feeding of these animals inside ESALQ, which may reduce the negative impacts on the local wildlife. Although ESALQ campus is used as a park by the local population for sports practice and leisure, the area harbors important biodiversity, and plays an essential role for wildlife conservation.

\section{Conclusion}

The mammal species list presented in our study is more complete than previous reported. The small-sized mammal assemblage (volant and non-volant) recorded is poor, composed of generalist species that are resilient enough to persist in HMLs. In contrast, the medium- and largesized assemblage presented higher species richness and, although mainly composed of generalist species, includes three nationally threatened species that reinforces the need for conservation measures. Small forest fragments are probably incapable of supporting viable populations of the species recorded, but they have an important role increasing the connectivity in HMLs. Therefore, we recommend restoration actions in the forest fragments focusing on medium- and large-sized mammals as umbrella species, as the implementation of safe crossing passages and road fencing to reduce roadkills, and control measures for reducing the impacts of domestic cats and dogs, improving the capability of this HML to act as refuge for mammal populations.

\section{Supplementary material}

The following online material is available for this article:

Appendix 1 - Species and individuals of small non-volant, and medium- and large-sized mammals preserved at the collection LMUSP recorded at Piracicaba, state of São Paulo, Brazil.

Appendix 2 - Species and individuals of small volant mammals preserved at the collection LMUSP and UFMG recorded at Piracicaba, state of São Paulo, Brazil.

Appendix 3 - Video.

Appendix 4 - Frequency of ocurrence (FO) and number of individuals (in parentheses) of mammals recorded in the three forest fragments of the study area in Piracicaba, state of São Paulo, Brazil.

Appendix 5 - Number of captured bat individuals by species, at Piracicaba, state of São Paulo, Brazil.

Appendix 6 - Dietary categories of the captured bat species at Piracicaba, state of São Paulo, Brazil.

\section{Acknowledgements}

We thank the Departamento de Ciências Florestais (Escola Superior de Agricultura "Luiz de Queiroz", Universidade de São Paulo), the Programa de Pós-Graduação em Recursos Florestais (PPGRF), the Programa Interunidades de Pós-Graduação em Ecologia Aplicada (PPGI-EA), the Laboratório de Ecologia, Manejo e Conservação de Fauna Silvestre (LEMaC), the Superintendência de Gestão Ambiental (SGA), the Plano Diretor do campus "Luiz de Queiroz", the Prefeitura do campus "Luiz de Queiroz" and Instituto de Pesquisas e Estudos Florestais (IPEF). We thank Ariovaldo C. Neto and Roberto Haddad for providing the previous data on bat inventory and Elson F Lima, Erica V. Maggiorini, Fernanda V. Giannini, Luana Amorim and Victor H. Andrade for helping in data collection. We also thank IPEF for the grant conceded to AAAB and JCZG. We thank the Conselho Nacional de Desenvolvimento Científico e Tecnológico (CNPq) for the scholarship conceded to CK, financial support (\#561910/2010-3), and the productivity fellowship granted to KMPMBF (\#308503/2014-7), to ARP (\#307519/2015-5) and to MARM. We thank the Fundação de Amparo à Pesquisa do Estado de São Paulo (FAPESP) for the grants to AAAB (\#2013/24929-9 and \#2014/23809-2), ARP (\#2009/16009-1), MBL 
(\#2013/18046-7), MM (\#2014/10192-7) and KMPMBF (\#2014/09300$0)$. We also thank the Brazilian Coordination for the Improvement of Higher Education Personnel (CAPES) for the scholarships granted to MM, MZAM and VA, and funding MARM. MARM was also funded by the Minas Gerais Research Foundation (FAPEMIG), Research Dean of Federal University of Minas Gerais (PRPq-UFMG), Alexander von Humboldt Foundation ( $\mathrm{AvH})$, and the Research Program on the Biodiversity of the Atlantic Forest (PPBio-MA).

\section{Author contributions}

Alex Augusto de Abreu Bovo: Substantial contribution in the concept and design of the study; Contribution to data collection; Contribution to data analysis and interpretation; Contribution to manuscript preparation; Contribution to critical revision, adding intelectual content.

Marcelo Magioli: Substantial contribution in the concept and design of the study; Contribution to data collection; Contribution to data analysis and interpretation; Contribution to manuscript preparation; Contribution to critical revision, adding intelectual content.

Alexandre Reis Percequillo: Contribution to data collection; Contribution to data analysis and interpretation; Contribution to manuscript preparation; Contribution to critical revision, adding intelectual content.

Cecilia Kruszynski: Contribution to data collection; Contribution to data analysis and interpretation; Contribution to manuscript preparation; Contribution to critical revision, adding intelectual content.

Vinicius Alberici: Contribution to manuscript preparation; Contribution to critical revision, adding intelectual content.

Marco A. R. Mello: Contribution to manuscript preparation; Contribution to critical revision, adding intelectual content.

Lidiani Silva Correa: Contribution to data collection; Contribution to manuscript preparation.

João Carlos Zecchini Gebin: Contribution to data collection.

Yuri Geraldo Gomes Ribeiro: Contribution to data collection.

Francisco Borges Costa: Contribution to data collection.

Vanessa Nascimento Ramos: Contribution to data collection.

Hector Ribeiro Benatti: Contribution to data collection.

Beatriz Lopez: Contribution to data collection.

Maísa Z. A. Martins: Contribution to data collection; Contribution to manuscript preparation; Contribution to critical revision, adding intelectual content.

Thais Rovere Diniz-Reis: Contribution to data analysis and interpretation; Contribution to manuscript preparation; Contribution to critical revision, adding intelectual content.

Plínio Barbosa de Camargo: Contribution to data analysis and interpretation.

Marcelo Bahia Labruna: Contribution to data collection; Contribution to manuscript preparation;

Katia Maria Paschoaletto Micchi de Barros Ferraz: Substantial contribution in the concept and design of the study; Contribution to data analysis and interpretation; Contribution to manuscript preparation; Contribution to critical revision, adding intelectual content.

\section{Conflicts of interest}

The authors declare that they have no conflict of interest related to the publication of this manuscript.

\section{References}

ALEXANDRINO, E.R., BOVO, A.A.A., LUZ, D.T.A., COSTA, J.C., BETINI, G.S., FERRAZ, K.M.P.M.B. \& COUTO, H.T.Z. 2013. Aves do Campus "Luiz de Queiroz" (Piracicaba, SP) da Universidade de São Paulo: mais de 10 anos de observações neste ambiente antrópico. Atual. Ornitol. 173: 40-52.

ALEXANDRINO, E.R., LUZ, D.T.A., MAGGIORINI, E.V. \& FERRAZ, K.M.P.M.D. 2012. Nest stolen: the first observation of nest predation by an invasive exotic marmoset (Callithrix penicillata) in an agricultural mosaic. Biota Neotrop. 12(2): 211-215 http://www.biotaneotropica.org.br/v12n2/pt/ fullpaper?bn01612022012+en (last accessed on 03/Sep/2017).

AVILA-FLORES, R. \& FENTON, M.B. 2005. Use of spatial features by foraging insectivorous bats in a large urban landscape. J. Mammal. 86(6): 1193-1204.

AYRAM, C.A.C., MENDOZA, M.E., ETTER, A. \& SALICRUP, D.R.P. 2015. Habitat connectivity in biodiversity conservation: a review of recent studies and applications. Prog. Phys. Geog. 40(1): 7-37.

BECA, G., VANCINE, M.H., CARVALHO, C.S., PEDROSA, F., ALVES, R.S.C., BUSCARIOL, D., PERES, C.A., RIBEIRO, M.C. \& GALETTI, M. 2017. High mammal species turnover in forest patches immersed in biofuel plantations. Biol. Conserv. 210: 352-359.

BECKER, M. \& DALPONTE, J.C. 1999. Rastros de mamíferos silvestres. Editora Universidade de Brasília. Brasília.

BECKMANN, J.P, CLEVENGER, A.P., HUIJSER, M.P. \& HILTY, J.A. 2010. Safe Passages: highways, wildlife, and habitat connectivity. Island Press, Washington.

BENAYAS, J.M.R., NEWTON, A.C., DIAZ, A. \& BULLOCK, J.M. 2009. Enhancement of biodiversity and ecosystem services by ecological restoration: a meta-analysis. Science, 325(5944): 1121-1124.

BOGONI, J.A., BOGONI, T.C., GRAIPEL, M.E. \& MARINHO, J.R. 2013. The influence of landscape \& microhabitat on the diversity of large-and mediumsized mammals in Atlantic Forest remnants in a matrix of agroecosystem $\&$ silviculture. ISRN Forestry 2013: 1-13.

BORGES, P.A.L. \& TOMÁS, W.M. 2008. Guia de rastros e outros vestígios de mamíferos do Pantanal. 1. ed. Embrapa Pantanal, Corumbá.

BORTOLOTTI, V.F.C. 2015. Riqueza, abundância e dieta de morcegos (Chiroptera) em floresta de eucaliptos. Monografia, Universidade Estadual Paulista "Júlio de Mesquita Filho", Rio Claro.

BOVO A.A.A., FERRAZ, K.M.P.M.B., VERDADE, L.M. \& MOREIRA, J.M. 2016. Capybaras (Hydrochoerus hydrochaeris) in anthropogenic environments: challenges \& conflicts. In Biodiversity in agricultural landscapes of southeastern Brazil. (C. Gheler-Costa, M.C. Lyra-Jorge \& L.M. Verdade, eds). De Gruyter Open, Berlin, p.178-189. http://dx.doi. org/10.1515/9783110480849-013

BRASIL. 2014. Ministério do Meio Ambiente. Lista Nacional Oficial das Espécies da Fauna Ameaçadas de Extinção. Portaria n. 444, de 17 de dezembro de 2014. Diário Oficial da União, Brasília www.icmbio.gov.br/ portal/images/stories/biodiversidade/fauna-brasileira/avaliacao-do-risco/ PORTARIA_No ${ }^{\circ}$ 444_DE_17_DE_DEZEMBRO_DE_2014.pdf(last access on $03 / \mathrm{Apr} / 2017)$.

BREDT, A. \& UIEDA, W. 1996. Bats from urban \& rural environments of the Distrito Federal, mid-western Brazil. Chirop. Neotrop. 2(2): 54-57.

CAMPOS, C.B., ESTEVES, C.F., FERRAZ, K.M.P.M.B. CRAWSHAW JR., P.G. \& VERDADE, L.M. 2007. Diet of free-ranging cats and dogs in a suburban and rural environment, south-eastern Brazil. J. Zool. 273(1): 14-20.

CHAVES, M.E., UIEDA, W., BOLOCHIO, C.E., SOUZA, C.A.I., BRAGA, D.D.A., FERREIRA, C.H., FIRMO, C.L., MARIANO, R.G.G.C., OLIVEIRA, K.C.S., SANTOS, E.G. \& COSTA, F.M. 2012. Bats (Mammalia: Chiroptera) from Guarulhos, state of São Paulo, Brazil. Check List 8(6): 1117-1121. 
CHIARELLO, A.G. 2000a. Conservation value of a native forest fragment in a region of extensive agriculture. Rev. Bras. Biol. 60(2): 237-247.

CHIARELLO, A.G. 2000b. Density and population size of mammals in remnants of Brazilian Atlantic Forest. Conserv. Biol. 14(6): 1649-1657.

DEAN, W. 1997. With broadax \& firebrand: the destruction of the Brazilian Atlantic Forest. University of California Press.

DOTTA, G. \& VERDADE, L.M. 2011. Medium to large-sized mammals in agricultural landscapes of south-eastern Brazil. Mammalia 75(4): 345-352.

EMMONS, L.H. \& FEER, F. 1997. Neotropical rainforest mammals: a field guide. University of Chicago Press, Chicago.

FALK-PETERSEN, J., BØHN, T. \& SANDLUND, O.T. 2006. On the numerous concepts in invasion biology. Biol. Invasions 8(6): 1409-1424.

FERRAZ, K.M.P.M.B., PETERSON, A.T., SCACHETTI-PEREIRA, R., VETTORAZZI, C.A. \& VERDADE, L.M. 2009. Distribution of capybaras in an agroecosystem, Southeastern Brazil, based on ecological niche modeling. J. Mammal. 90(1): 189-194.

FILHO, H.O. 2011. Bats in natural \& urban environments. In: 7th International Conference on Urban Pests, Ouro Preto, Brazil, 7-10 August 2011, 13-15.

GARDNER, A.L. 2007. Mammals of South America, v.1, Marsupials, Xenarthrans, Shrews, \& Bats. University of Chicago Press, Chicago.

GERHOLD, R.W. \& JESSUP, D.A. 2013. Zoonotic diseases associated with free-roaming cats. Zoonoses Public Health, 60(3): 189-195.

GHELER-COSTA, C., SABINO-SANTOS JR., G., AMORIM, L.S., ROSALINO, L.M., FIGUEIREDO, L.T.M. \& VERDADE, L.M. 2013. The effect of pre-harvest fire on the small mammal assemblage in sugarcane fields. Agric. Ecosyst. Environ. 171: 85-89.

GHELER-COSTA, C., VERDADE, L.M. \& ALMEIDA, A.D. 2002. Mamíferos não-voadores do campus" Luiz de Queiroz", Universidade de São Paulo, Piracicaba, Brasil. Rev. Bras. Zool. 19(2): 203-214.

GREGORIN, R. \& TADDEI, V.A. 2002. Chave artificial para a identificação de molossídeos brasileiros (Mammalia, Chiroptera). Mastozool. Neotrop. 9(1): 13-32.

HUIJSER, M.P., FAIRBANK, E.R., CAMEL-MEANS, W., GRAHAM, J., WATSON, V., BASTING, P. \& BECKER, D. 2016. Effectiveness of short sections of wildlife fencing and crossing structures along highways in reducing wildlife-vehicle collisions and providing safe crossing opportunities for large mammals. Biol. Conserv. 197, 61-68.

IBGE - INSTITUTO BRASILEIRO DE GEOGRAFIA E ESTATÍSTICA. 2004. Mapa de biomas do Brasil. ftp://ftp.ibge.gov.br/Cartas e Mapas/ Mapas_Murais/biomas_pdf.zip (last access on 10/Dec/2010).

IUCN - INTERNATIONAL UNION FOR CONSERVATION OF NATURE AND NATURAL RESOURCES. 2016. IUCN Red List of Threatened Species. Version 2016.3. www.iucnredlist.org (last accessed on 23/ Nov/2016)

JACOMASSA, F.A.F. 2015. Assembleia, frugivoria e biologia reprodutiva de morcegos em áreas restauradas. Tese. Universidade Estadual Paulista "Júlio de Mesquita Filho", Rio Claro.

JORGE, M.L.S., GALETTI, M., RIBEIRO, M.C. \& FERRAZ, K.M.P.M.B 2013. Mammal defaunation as surrogate of trophic cascades in a biodiversity hotspot. Biol. Conserv. 163: 49-57.

JUNG, K. \& KALKO, E.K. 2011. Adaptability \& vulnerability of high flying Neotropical aerial insectivorous bats to urbanization. Divers. Distrib. 17(2), 262-274.

KUNZ, T.H. \& ANTHONY, E.L. 1982. Age estimation \& post-natal growth in the bat Myotis lucifugus. J. Mammal. 63(1): 23-32.

LOSS, S.R., WILL, T. \& MARRA, P.P. 2013. The impact of free-ranging domestic cats on wildlife of the United States. Nature Communications 4: 1396.

LYRA-JORGE, M.C., RIBEIRO, M.C., CIOCHETI, G., TAMBOSI, L.R. \& PIVELLO, V.R. 2010. Influence of multi-scale landscape structure on the occurrence of carnivorous mammals in a human-modified savanna, Brazil. Eur. J. Wildl.Res. 56(3): 359-368.
MAGIOLI, M., FERRAZ, K.M.P.M.B. \& RODRIGUES, M.G. 2014a. Medium and large-sized mammals of an isolated Atlantic Forest remnant, southeast São Paulo State, Brazil. Check List 10(4): 850-856.

MAGIOLI, M., FERRAZ, K.M.P.M.B., SETZ, E.F., PERCEQUILLO, A.R., RONDON, M.V.S.S., KUHNEN, V.V., CANHOTO, M.C.S., SANTOS, K.E.A., KANDA, C.Z., FREGONEZI, G.L., PRADO, H.A., FERREIRA, M.K., RIBEIRO, M.C., VILLELA, P.M.S., COUTINHO, L.L. \& RODRIGUES, M.G. 2016. Connectivity maintain mammal assemblages functional diversity within agricultural and fragmented landscapes. Eur. J. Wildl. Res. 62(4): 431-446

MAGIOLI, M., MOREIRA, M.Z., FERRAZ, K.M.P.M.B., MIOTTO, R.A., CAMARGO, P.B., RODRIGUES, M.G., CANHOTO, M.C.S. \& SETZ, E.Z.F. 2014b. Stable isotope evidence of Puma concolor (Felidae) feeding patterns in agricultural landscapes in southeastern Brazil. Biotropica 46(4): 451-460.

MAGIOLI, M., RIBEIRO, M.C., FERRAZ, K.M.P.M.B. \& RODRIGUES, M.G 2015. Thresholds in the relationship between functional diversity \& patch size for mammals in the Brazilian Atlantic Forest. Animal Conservation 18(6): 499-511.

MELO, F. P., ARROYO-RODRÍGUEZ, V., FAHRIG, L., MARTÍNEZ-RAMOS, M. \& TABARELLI, M. 2013. On the hope for biodiversity-friendly tropical landscapes. Trends Ecol. Evol. 28(8), 462-468.

MIOTTO, R.A., CERVINI, M., KAJIN, M., BEGOTTI, R.A. \& GALETTI, P.M. 2014. Estimating puma Puma concolor population size in a human-disturbed landscape in Brazil, using DNA mark-recapture data. Oryx 48(02): 250-257.

NOGUEIRA, M.R., LIMA, I.P., MORATELLI, R., TAVARES, V.D.C., GREGORIN, R. \& PERACCHI, A.L. 2014. Checklist of Brazilian bats, with comments on original records. Check List 10(4): 808-821. http:// dx.doi.org/10.15560/10.4.808

OLIVEIRA, T.G. \& CASSARO, K. 2006. Guia de campo dos felinos do Brasil. Instituto Pró-Carnívoros; Fundação do Parque Zoológico de São Paulo, Sociedade de Zoológicos do Brasil, Pró-Vida Brasil, São Paulo.

PACHECO, S.M., SODRÉ, M., GAMA, A.R., BREDT, A., CAVALLINI, E.M., MARQUES, R.V., GUIMARÃES, M.M. \& BIANCONI, G. 2010. Morcegos urbanos: status do conhecimento e plano de ação para a conservação no Brasil. Chirop. Neotrop. 16(1): 629-647.

PAGLIA, A.P., FONSECA, G.A.B., RYLANDS, A.B., HERMANN, G., AGUIAR, L.M.S., CHIARELLO, A.G., LEITE, Y.L.R., COSTA, L.P., SICILIANO, S., KIERULFF, M.C.M., MENDES, S.L., TAVARES, V.C., MITTERMEIER, R.A. \& PATTON, J.L. 2012. Annotated Checklist of Brazilian Mammals. 2. Ed. Occasional Papers in Conservation Biology, No. 6. Conservation International, Arlington, VA.

PARDINI, R. \& UMETSU, F. 2006. Pequenos mamíferos não voadores da reserva florestal Morro Grande - distribuição das espécies e da diversidade em uma área de Mata Atlântica. Biota Neotrop. 6(2): 1-22 http://www. biotaneotropica.org.br/v6n2/pt/abstract?article+bn00606022006 (last accessed on 03/Sep/2016).

PASSOS, F.C., SILVA, W.R., PEDRO, W.A. \& BONIN, M.R. 2003. Frugivoria em morcegos (Mammalia, Chiroptera) no Parque Estadual Intervales, sudeste do Brasil. Rev. Bras. Zool. 20: 511-517.

PATTON, J.L., PARDIÑAS, U.F.J. \& D'ELÍA, G. 2015. Mammals of South America, v. 2, Rodents. University of Chicago Press, Chicago.

PERCEQUILLO, A.R. \& KIERULFF, C. 2009. Mamíferos. In Fauna ameaça de extinção do Estado de São Paulo: vertebrados (Breassan, P.M., Kierulff, M.C.M. \& Sugieda, A.M. eds.). Fundação Parque Zoológico de São Paulo, Secretaria do Meio Ambiente, São Paulo. pp. 31-41.

PEREIRA, S.N., DIAS, D., LIMA, I.P., MAAS, A.C.S., MARTINS, M.A., BOLZAN, D.P., FRANÇA, D.S., OLIVEIRA, M.B., PERACCHI, A.L. \& FERREIRA, M.F.S. 2013. Mamíferos de um Fragmento Florestal em Volta Redonda, Estado do Rio de Janeiro. Biosci. J. 29(4): 1017-1027.

PERES, C.A., GARDNER, T.A., BARLOW, J., ZUANON, J., MICHALSKI, F., LEES, A.C., VIEIRA, I.C.G., MOREIRA, F.M.S. \& FEELEY, K.J. 2010 Biodiversity conservation in human-modified Amazonian forest landscapes. Biol. Conserv. 143(10): 2314-2327. 
R CORE TEAM. 2016. R: A language and environment for statistical computing. R Foundation for Statistical Computing, Vienna, Austria. http://www.Rproject.org. (last access on 14/Nov/2016).

REALE, R., FONSECA, R.C.B. \& UIEDA, W. 2014. Medium \& large-sized mammals in a private reserve of natural heritage in the municipality of Jaú, São Paulo, Brazil. Check List 10(5): 997-1004.

RIBEIRO, M.C., METZGER, J.P., MARTENSEN, A.C., PONZONI, F.J. \& HIROTA, M.M. 2009. The Brazilian Atlantic Forest: how much is left, and how is the remaining forest distribuited? Implications for conservation. Biol. Conserv. 142(6): 1141-1153.

ROSALINO, L.M., MARTIN, P.S., GHELER-COSTA, C., LOPES, P.C. \& VERDADE, L.M. 2014. Neotropical small mammals' diversity in the early cycle of commercial Eucalyptus plantations. Agrofor. Syst. 88(3): 427-436.

RYLANDS, A.B., COIMBRA-FILHO, A.F. \& MITTERMEIER, R.A. 2009. The systematics and distributions of the marmosets (Callithrix, Callibella, Cebuella, and Mico) and callimico (Callimico)(Callitrichidae, Primates). In The smallest anthropoids (S.M. Ford, L.M. Porter \& L.C. Davis). Springer, New York, p.25-61.

RYTWINSKI, T., SOANES, K., JAEGER J. A. G., FAHRIG, L., FINDLAY, C.S., HOULAHAN, J., VAN DER REE, R. \& VAN DER GRIFT, E.A. 2016. How effective is road mitigation at reducing road-kill? A meta-analysis. PLoS ONE 11: e0166941.

SACILOTO, G.A.Z. 2009. Inventário de mastofauna de médio e grande porte na Estação Experimental de Tupi - Piracicaba - SP. Monografia, Universidade Metodista de Piracicaba, Piracicaba.

SANTOS, K.K., PACHECO, G.S.M. \& PASSAMANI, M. 2016. Medium-sized \& large mammals from Quedas do Rio Bonito Ecological Park, Minas Gerais, Brazil. Check List 12(1): 1830.

SIKES, R.S. \& THE ANIMAL CARE AND USE COMMITTEE OF THE AMERICAN SOCIETY OF MAMMALOGISTS. 2016. Guidelines of the American Society of Mammalogists for the use of wild mammals in research and education. J. Mammal. 97(3): 663-688, https://doi.org/10.1093/ jmammal/gyw078

SILES, L., PEÑARANDA, D., PÉREZ-ZUBIETA, J.C. \& BARBOZA, K. 2005. Los murciélagos de la ciudad de Cochabamba. Rev. Bol. de Ecol. 18: 51-64.
SILVA, A.P. JR. \& PONTES, A.R. 2008. The effect of a mega-fragmentation process on large mammal assemblages in the highly-threatened Pernambuco Endemism Centre, north-eastern Brazil. Biodiv. Conserv. 17(6): 1455-1464.

SOARES-FILHO, B., RAJÃO, R., MACEDO, M., CARNEIRO, A., COSTA, W., COE, M., RODRIGUES, H. \& ALENCAR, A. 2014. Cracking Brazil's forest code. Science 344(6182): 363-364.

SOS MATA ATLÂNTICA. 2017. Atlas dos remanescentes florestais da Mata Atlantica período 2015-2016. São Paulo, Brasil. Fundação SOS Mata Atlantica. Instituto Nacional das Pesquisas Espaciais.

STICKLER, C.M., NEPSTAD, D.C., AZEVEDO, A.A. \& MCGRATH, D.G. 2013. Defending public interests in private lands: compliance, costs $\&$ potential environmental consequences of the Brazilian Forest Code in Mato Grosso. Philos. T. Roy. Soc. B. 368(1619): 20120160.

STRAUBE, F.C. \& BIANCONI, G.V. 2002. Sobre a grandeza e a unidade utilizada para estimar esforço de captura com utilização de redes-deneblina. Chirop. Neotrop. 8(1/2): 150-152. http://dx.doi.org/10.1017/ CBO9781107415324.004

TEIXEIRA, F.Z., COELHO, A.V.P., ESPERANDIO, I.B. \& KINDEL, A. 2013. Vertebrate road mortality estimates: effects of sampling methods and carcass removal. Biol. Conserv.157, 317-323.

TRIGO, T.C., SCHNEIDER, A., OLIVEIRA, T.G., LEHUGEUR, L.M., SILVEIRA, L., FREITAS T.R. \& EIZIRIK, E. 2013. Molecular data reveal complex hybridization \& a cryptic species of Neotropical wild cat. Curr. Biol. 23(24): 2528-2533.

VIVO, M., CARMIGNOTTO, A.P., GREGORIN, R., HINGST-ZAHER, E., IACK-XIMENES, G.E., MIRETSKI, M., PERCEQUILLO, A.R., ROLLO JR., M.M., ROSSI, R.V. \& TADEI, V.A. 2011. Checklist dos mamíferos do Estado de São Paulo, Brasil. Biota Neotrop. 11(1a): 1-21 http://www. biotaneotropica.org.br/v11n1a/pt/abstract?article+bn0071101a2011 (last accessed on $02 / \mathrm{sep} / 2016$ )

VOSS, R.S. \& EMMONS, L.H. 1996. Mammalian diversity in neotropical lowland rainforests: a preliminary assessment. Bull. Am. Mus. Nat. His. 230.

WOODS, M., MCDONALD, R.A. \& HARRIS, S. 2003. Predation of wildlife by domestic cats Felis catus in Great Britain. Mammal Rev. 33: 174-188.

Received: $21 / 06 / 2017$ Revised: 02/02/2018

Accepted: 22/02/2018

Published online: 09/04/2018 